\title{
The Role of Personality in Second Language Acquisition
}

\author{
Yan Zhang \\ Qingdao University of Science and Technology, Qingdao 266000, China \\ E-mail: tudoucoco@yahoo.com.cn
}

\begin{abstract}
Second language learners vary on a number of dimensions to do with personality, motivation, learning style, aptitude and age. The aim of this paper is to illustrate and summarize the relationship between personality and second language acquisition.
\end{abstract}

Keywords: Extrovert, Introvert, Second language acquisition

Introduction

Second language acquisition is defined as the learning and adopting of a language that is not your native language. Once you have acquired a foreign language, you have mastered that language. For second language learners to make maximum progress with their own learning styles, their individual differences must be recognized and attended to. A number of theories hold that personality factors significantly influence the degree of success that individuals achieve in learning a second language (Gass \& Selinker, 1994) based on the assumption that some features of the learner's personality might encourage or inhibit second language learning (Cook, 1996) by enhancing certain facets of language learning while impeding others (Larsen-Freeman \& Long, 1991). We are going to illustrate it in detail.

\section{Definitions of extroversion \& introversion}

Extrovert and introvert are two characterizations of how one relates to the outside world. Extrovert means a person more interested in what is happening around him than in his own thoughts and emotions. That is to say, the extrovert experiences the world more through contact with others and shared experience than through self examination or study. If the problem were to come about for an extrovert, they would more than just likely find someone to help. On the contrary, introvert is a person who is more interested in his own thoughts and feelings than in things outside himself, and is often shy and unwilling to speak or join in activities with others. In other words, an introvert tends to remain "in" oneself. If the same problem were to arise, that person might open a book or pace back and forth to come to a solution.

\section{The relationship between extroversion \& introversion and second language acquisition}

Second language acquisition may be more difficult for some people due to certain social factors. One highly studied social factor impeding language development is the issue of extraverts versus introverts. Studies have shown that extraverts (or unreserved and outgoing people) acquire a second language better than introverts (or shy people).One particular study done by Naiman reflected this point. The subjects were 72 Canadian high school students from grades 8 , 10 and 12 who were studying French as a second language. Naiman gave them all questionnaires to establish their psychological profiles, which also included a French listening test and imitation test. He found that approximately $70 \%$ of the students with the higher grades (B or higher) would consider themselves extraverts. Extraverts will be willing to try to communicate even if they are not sure they will succeed. Introversion has the greatest chance of negatively affecting SLA. Students that are afraid of embarrassing themselves by speaking incorrectly or by not being able to speak at all may try to avoid opportunities that would otherwise aid their learning.

Related to the extroversion/ distinction are the types of social skills involved in second language acquisition. Wesche (1977), studying thirty-seven Canadian civil servants in an intensive French course, found a correlation between "role playing" and proficiency in listening comprehension and speaking skills $(r=0.60)$. "Role-playing" referred to the willingness of the student to take the part of a character in a dialogue or role-playing situation, "with speech characterized by prosodic expressions of feeling appropriate to the context and by accompanying gestures and facial expressions" (p. 359). This could reflect extroversion, self-confidence, and/or satisfaction with the learning situation, as well as general anxiety level. Two scientists, Kinginger and Farrell, conducted interviews with U.S. students after their study abroad program in France in 2003. They found that many of the students would avoid interaction with the native speakers at all costs, while others jumped at the opportunity to speak the language. Those who avoided interaction were typically quiet, reserved people, (or introverts). Therefore, if teachers correct mistakes and further embarrass shy students, it may isolate students even more. Instead, repeating back the corrected statement allows feedback without a damaging student's ego. For example, if Marcia says "Yesterday I go to the store with my madre," the teacher would 
respond, "You went to the store with your mother yesterday?" She has effectively provided corrected input while also continuing the conversation. If a student shuts down after an outright correction then opportunity for more input and practice has been lost.

\section{The development of personality}

Since Studies have shown that extroverts (or unreserved and outgoing people) acquire a second language better than introverts (or shy people), it seems also important for second language learners to develop personality. That is to say, try to be extrovert while study a second language. As everybody knows, individuality is one thing and personality is another. A soul is born an individual, but without a personality. Personality is built after one is born. What the soul has brought along is hands and legs and face, but not personality; this is made here on earth. Some hereditary factors that contribute to personality development do so but some potential environmental influences that help to shape personality. It is entirely commendable to devote some thought and effort to the improvement of your personality that can help you to learn second language better.

\section{Implications for teaching second language}

According to what I mentioned above, teachers' teaching methodology should be adapted to the individual differences in personality, in order to enhance the progress for the second language learners. However, complete individualization is not always possible in the classroom, for different learners respond differently to the same input as a function of the ways in which their personality affects their perception and interpretation of the world, but may be more easily realized in multimedia CALL. One advantage of multimedia CALL is its potential adaptability; when users control their learning environment, they can intuitively select the options best suited for their learning style preferences.

\section{Conclusion}

In a word, a number of theories and case studies tell that personality factors significantly influence the degree of success that individuals achieve in learning a second language. Especially, lots of studies have shown that extroverts (or unreserved and outgoing people) acquire a second language better than introverts (or shy people). That indicates a new light on the second language teaching methodology.

\section{References}

Chapelle, C. A., \& Robert, C. (1986). Ambiguity tolerance and field independence as predictors of proficiency in English as a Second Language. Language Learning, 36, 27-45.

Cook, V. (1996). Second language learning andhttp://g6a55.mail.163.com/a/f/js3/0801290924/htmltool_js3_v1.htm second language teaching ( $2^{\text {nd }}$ ed.). New York: Arnold.

Gass, S., \& Selinker, L. (1994). Second language acquisition: An introductory course. Hillsdale, NJ: Lawrence Erlbaum.

Larsen-Freeman, D., \& Long, M. (1991). An introduction to second language acquisition research. London: Longman.

Naiman, N., Frohlich, M., \& Todesco, A. (1975). The good second language learner. TESL Talk, 5, 58-75.

Naiman, N., Frohlich, M., Stern, H., \& Todesco, A. (1978). The good second language learner (Research in Education Series No.7). Toronto: Ontario Institute for Studies in Education.

Ellis. R. (1985) Understanding Second Language Acquisition. Oxford University Press.

Wesche, M. (1977) "Learning behaviors of successful adult students on intensive language training." Paper presented at Los Angeles Second Language Acquisition Forum, UCLA, 1977. 